\title{
Faktor-Faktor yang Berhubungan Dengan Status Imunisasi (DPT-HB-Hib) Pada Bayi
}

\author{
Bina Aquari ${ }^{1}$, Elvera ${ }^{2}$, Fransiska ${ }^{3}$ \\ Akademi Kebidanan Budi Mulia Palembang ${ }^{123}$
}

Informasi Artikel :

Diterima : 02 November 2021

Direvisi : 09 November 2021

Disetujui : 01 Desember 2021

Diterbitkan : 30 Desember 2021

*Korespondensi Penulis : binaplb2201@gmail.com

\begin{abstract}
A B S T R A K
Imunisasi merupakan salah satu upaya kesehatan masyarakat esensial yang efektif untuk memberikan kekebalan spesifik terhadap Penyakit yang Dapat Dicegah dengan Imunisasi (PD3I). Adanya COVID-19 yang terjadi secara global dan ditetapkan sebagai pandemi oleh WHO, memberikan dampak pada pelaksanaan program kesehatan khususnya pelayanan imunisasi dan surveilans PD3I. Vaksin Pentavalen merupakan pengembangan vaksin Tetravalen (DPT-HB) dengan penambahan antigen Haemophilus influenzae type b (Hib). Kini kelima antigen tersebut diberikan dalam satu suntikan sehingga lebih efisien, tidak menambah jumlah suntikan walaupun dengan penambahan antigen, sehingga memberikan kenyamanan bagi bayi dan ibunya Data cakupan penta 1 (DPTHBHiB 1) menunjukkan bahwa sampai dengan bulan April 2020, lebih dari 500,000 bayi belum mendapatkan imunisasi penta 1 , dengan penurunan terbesar terjadi di bulan April 2020 yaitu 50,1\% dibandingkan tahun 2019. Hal yang sama juga terjadi pada cakupan penta 3 (DPT-HB-HiB 3). Sampel penelitian diambil dari total populasi secara Non Random dengan menggunakan teknik Accidental Sampling yaitu dengan mengambil kasus atau responden yang kebetulan ada atau tersedia, yaitu pada saat ibu-ibu membawa bayi usia $\geq 1$ tahun yang mau mendapatkan pelayanan imunisasi dasar di Klinik/BP Anisa Kecamatan Sembawa Kabupaten Banyuasin yang berjumlah 46 responden. Hasil penelitian didapatkan ada hubungan antara pekerjaan ibu, pendidikan ibu, keterjangkauan tempat pelayanan kesehatan secara simultan dengan Status Imunisasi (DPT-HB-Hib) Pada Bayi dan Balita di Klinik/BP Anisa Kec. Sembawa Kab. Banyuasin Tahun 2021. Sebagai bahan masukan bagi Klinik/BP Anisa, khususnya bagi bidan dalam menjalankan perannya untuk mengembangkan program edukasi dan konseling kepada Ibu yang mempunyai bayi dalam pemberian imunisasi.
\end{abstract}

\section{Kata Kunci : Imunisasi (DPT-HB-Hib)}

\section{ABSTRACT}

Immunization is one of the essential effective public health efforts to provide specific immunity against Immunization Preventable Diseases (PD3I). The existence of COVID-19 that occurred globally and was designated as a pandemic by WHO, had an impact on the implementation of health programs, especially immunization services and PD3I surveillance. Pentavalent vaccine is the development of Tetravalent vaccine (DPT-HB) with the addition of Haemophilus influenzae type $b$ (Hib) antigen. Now the five antigens are given in one injection so that it is more efficient, does not increase the number of injections even with the addition of antigens, thus providing comfort for the baby and mother. penta 1 immunization, with the largest decrease occurring in April 2020, namely 50.1\% compared to 2019. The same thing happened to 
penta 3 (DPT-HB-HiB 3) coverage. The research sample was taken from the total population non-randomly using the Accidental Sampling technique, namely by taking cases or respondents who happened to exist or were available, namely when mothers brought babies aged 1 year who wanted to get basic immunization services at the Anisa Clinic/BP District. Sembawa Banyuasin Regency, totaling 46 respondents. The results showed that there was a relationship between mother's occupation, mother's education, affordability of health care facilities simultaneously with Immunization Status (DPT-HB-Hib) in Infants and Toddlers at Anisa Clinic/BP Kec. Sembawa Kab. Banyuasin 2021. As input for Anisa Clinic/BP, especially for midwives in carrying out their role in developing education and counseling programs for mothers who have babies in giving immunizations.

\section{Keywords: Immunization (DPT-HB-Hib)}

\section{PENDAHULUAN}

Imunisasi merupakan salah satu upaya kesehatan masyarakat esensial yang efektif untuk memberikan kekebalan spesifik terhadap Penyakit yang Dapat Dicegah dengan Imunisasi (PD3I). Adanya COVID-19 yang terjadi secara global sejak ditetapkan sebagai Public Health Emergency of International Concern (PHEIC) pada tanggal 30 Januari 2020 dan ditetapkan sebagai pandemi pada tanggal 11 Maret 2020 oleh WHO, memberikan dampak pada pelaksanaan program kesehatan khususnya pelayanan imunisasi dan surveilans PD3I. Berdasarkan data yang diperoleh dari GAVI, WHO dan UNICEF menyebutkan bahwa setidaknya 80 juta anak usia kurang dari 1 tahun memiliki risiko untuk menderita penyakit difteri, campak dan polio akibat terganggunya pelayanan imunisasi rutin di tengah pandemi COVID-19. Terdapat 64\% dari 107 negara mengalami gangguan atau penundaan pelaksanaan layanan imunisasi rutin dan 60 negara menunda pelaksanaan kampanye imunisasi terutama campak dan polio. Hal ini tentu berisiko untuk terjadinya Kejadian Luar Biasa (KLB) (Vina et al.2017)

Vaksin Pentavalen merupakan pengembangan vaksin Tetravalen (DPT-HB) dengan penambahan antigen Haemophilus influenzae type b (Hib). Kini kelima antigen tersebut diberikan dalam satu suntikan sehingga lebih efisien, tidak menambah jumlah suntikan walaupun dengan penambahan antigen, sehingga memberikan kenyamanan bagi bayi dan ibunya. Data cakupan penta 1 (DPTHBHiB 1) menunjukkan bahwa sampai dengan bulan April 2020, lebih dari 500,000 bayi belum mendapatkan imunisasi penta 1 , dengan penurunan terbesar terjadi di bulan April 2020 yaitu $50.1 \%$ dibandingkan tahun 2019. Hal yang sama juga terjadi pada cakupan penta 3 (DPT-HB-HiB 3). (Ibrahim,2016)

DTP acellular dan vaksin influenza dalam beberapa bulan terakhir langka di pasaran karena berbagai alasan, antara lain permintaan global yang meningkat, masalah produksi, dan distribusi vaksin tersebut. Untuk mencukupi seluruh kebutuhan global perlu waktu 1-2 tahun. Hal ini akan dibicarakan dalam rapat Strategic Advisory Group of Experts (SAGE) on Immunization di WHO Geneva bulan April 2016. Saat ini Indonesia kekurangan vaksin tersebut, sehingga timbul beberapa masalah yang menjadi pertanyaan anggota IDAI mengenai penggantian vaksin DTP acellular dan vaksin influenza. (P3K Nakes,2014).

Cakupan program imunisasi dasar dan lanjutan di Sumatera Selatan di Tahun 2020 baru mencapai $35 \%$ persen karena terjadi 
penyusutan akumulasi sejak pandemic COVID-19, kasi surveillance dan imunisasi Dinas Kesehatan (Dinkes) Sumsel mengatakan kondisi pandemic selama dua bulan terakhir memaksa program imunisasi hanya dilaksanakan di puskesmas dengan protocol kesehatan yang ketat, dampaknya akses untuk mendapatkan imunisasi menjadi terbatas. 10

Salah satu tempat yang melaksanakan program imunisasi di Kabupaten Banyuasin adalah Klinik/BP Anisa. Data dari Klinik/BP Anisa pada bulan januari 2020 vaksin pentabio kosong, bulan juli 2020 vaksin pentabio kosong, dan di tahun 2021 bulan Juni, juli, september, vaksin pentabio kosong, dengan rata - rata bayi yang disuntik imunisasi pentabio setiap bulan di Klinik/BP Anisa yaitu berjumlah 25-30 bayi, Ini menunjukan bahwa menurunnya jumlah bayi yang mendapatkan imunisasi pentabio dikarenakan kosongnya ketersediaan vaksin pentabio, ini bukan hanya terjadi di Klinik/BP Anisa tapi ditempat pelayanan imunisasi lain seperti puskesmas, pustu dan klinik yang lain diseluruh kabupaten Banyuasin.(Medical Record Klinik/BP Anisa, Tahun 2020/2021). (Dinkes Kota,2020)

Dari uraian di atas menunjukkan bahwa saat ini dunia khususnya di Indonesia, sedang mengalami krisis kesehatan yang berdampak pada penurunan pelayanan kesehatan salah satunya adalah imunisasi, maka dari itu penulis tertarik untuk melakukan penelitian mengenai " Faktor Faktor Yang Berhubungan dengan Status Imunisasi (DPT-HB-Hib) Pada Bayi dan Balita di Klinik/BP Anisa Kecamatan Sembawa Kabupaten Banyuasin Tahun 2021"

\section{METODE PENELITIAN}

Desain penelitian action research adalah untuk mencari suatu dasar pengetahui praktik guna memperbaiki suatu situasi atau keadaan kesehatan masyarakat, yang di lakukan secara terbatas di mana pemecahan masalah perlu di lakukan dan hasilnya di perlukan untuk memperbaiki suatu keadaan. (Notoadmojo, 2010). (Nanda,2020).

Populasi dalam penelitian ini adalah semua ibu yang yang membawa bayinya usia $\geq 1$ tahun pada saat pemeriksaan yang berjumlah 46 orang. Sampel penelitian diambil dari total populasi secara Non Random dengan menggunakan teknik Accidental Sampling yaitu dengan mengambil kasus atau responden yang kebetulan ada atau tersedia, yaitu pada saat ibu-ibu membawa bayi usia $\geq 1$ tahun yang mau mendapatkan pelayanan imunisasi dasar di Klinik/BP Anisa Kecamatan Sembawa Kabupaten Banyuasin yang berjumlah 46 responden. (Notoadmodjo, 2005)

Kriteria inklusi pada penelitian ini yaitu responden bersedia menjadi objek penelitian dan hadir saat pengambilan data, ibu yang memiliki anak usia $\geq 1$ tahun, serta memiliki kartuKMS yang sudah terisi catatan imunisasi.

Analisa Data dalam penelitian ini ada 2 yaitu : Analisa Univariat yaitu untuk mengetahui distribusi frekuensi dan persentase dari semua variabel penelitian yaitu pekerjaan ibu, pendidikan ibu, keterjangkauan tempat pelayanan kesehatan (variabel independen) serta Status Imunisasi (DPT-HB-Hib) Pada Bayi (variabel dependen). Analisa Bivariat untuk melihat adanya hubungan pekerjaan ibu, pendidikan ibu, keterjangkauan tempat pelayanan kesehatan dengan Status Imunisasi (DPT-HBHib) Pada Bayi yang disajikan dalam bentuk tabel yang dianalisa dengan Uji Chi-Square. $\left(\mathrm{X}^{2}\right)$ dengan batas kemaknaan pada $\alpha=0,05$ menggunakan system Komputerisasi Statistical Program For Sosial Sciense (SPSS) dengan teknis kepercayaan $95 \%(\alpha=0,05)$ dan df $=1$ dengan batas kemaknaan $P$ value $<$ 0,05 artinya ada hubungan yang bermakna / signifikan antara variabel independen dan 
Jurnal Kebidanan : Jurnal Medical Science Ilmu Kesehatan Akademi Kebidanan Budi Mulia Prabumulih Volume.11 No.2, Desember 2021

Available online https://journal.budimulia.ac.id/

variabel dependen dan Jika $P$ value $>0,05$ artinya tidak ada hubungan yang bermakna.

\section{HASIL PENELITIAN}

1. Hubungan Antara Pekerjaan Ibu dengan Untuk Status Imunisasi (DPTHB-Hib) Pada Bayi.

Pada penelitian ini yang dilakukan pada 46 responden dimana Pekerjaan Ibu dikategorikan menjadi 2 yaitu bekerja dan tidak bekerja dan Status Imunisasi (DPTHB-Hib) Pada Bayi di kategorikan menjadi 2 yaitu lengkap dan tidak lengkap.untuk lebih jelasnya dapat dilihat pada tabel 1 .

\section{Tabel 1 Distribusi Responden Berdasarkan Pekerjaan Ibu dengan Status Imunisasi (DPT-HB-Hib) Pada Bayi di Klinik/BP Anisa Tahun 2021}

\begin{tabular}{|c|c|c|c|c|c|c|c|c|}
\hline \multirow{3}{*}{ No } & \multirow{3}{*}{$\begin{array}{l}\text { Pekerjaan } \\
\text { Ibu }\end{array}$} & \multicolumn{4}{|c|}{$\begin{array}{c}\text { Status Imunisasi (DPT-HB- } \\
\text { Hib) Pada Bayi }\end{array}$} & \multirow{3}{*}{$\mathrm{N}$} & \multirow{3}{*}{$\%$} & \multirow[b]{2}{*}{ PValue } \\
\hline & & \multicolumn{2}{|c|}{ Lengkep } & \multicolumn{2}{|c|}{$\begin{array}{c}\text { Tidak } \\
\text { Lengkap }\end{array}$} & & & \\
\hline & & $\mathrm{n}$ & $\%$ & $\mathrm{n}$ & $\%$ & & & Pvalue \\
\hline 1. & bekerja & 12 & 41,4 & 17 & 58,6 & 29 & 100 & $\begin{array}{c}0,016 \\
\text { Bermakna }\end{array}$ \\
\hline 2. & tidak bekeja & 16 & 90 & 1 & 10 & 17 & 100 & \\
\hline & Jumlah & 33 & & 13 & & 46 & & \\
\hline
\end{tabular}

Berdasarkan tabel 1 diatas dari 29 responden ibu yang bekerja Status Imunisasi (DPT-HB-Hib) Pada Bayinya lengkap sebanyak 12 bayi $(41,4 \%)$ dan ibu yang bekerja yang Status Imunisasi (DPTHB-Hib) Pada Bayi tidak lengkap sebanyak 17 bayi $(58,6 \%)$ dan dari 17 responden ibu yang tidak bekerja yang Status Imunisasi (DPT-HB-Hib) Pada Bayi lengkap sebanyak 16 bayi (90\%) dan ibu tidak bekerja Status Imunisasi (DPT-HBHib) Pada Bayi tidak lengkap sebanyak 1 bayi (10\%).

Sedangkan berdasarkan uji statisti Chi Square, $\mathrm{df}=1$ dan batas kemaknaan $\alpha$ $=0,05$ dan didapat $p$ value $=0,016<0,05$. hal ini menunjukkan ada hubungan antara pekerjaan ibu dengan Status Imunisasi (DPT-HB-Hib) Pada Bayi sehingga hipotesis menyatakan ada hubungan antara umur ibu dengan Status Imunisasi (DPT-HB-Hib) Pada Bayi terbukti secara statistik

2. Hubungan Antara Pendidikan Ibu dengan Status Imunisasi (DPT-HB-Hib) pada Bayi.

Pada penelitian ini yang dilakukan pada 46 responden dimana pendidikan Ibu dikategorikan menjadi 2 yaitu tinggi dan rendah dan Status Imunisasi (DPT-HB-Hib) Pada Bayi di kategorikan menjadi 2 yaitu lengkap dan tidak lengkap.untuk lebih jelasnya dapat dilihat pada tabel 2

Tabel 2 Distribusi Responden Berdasarkan Pendidikan Ibu dengan Status Imunisasi (DPT-HB-Hib) pada Bayi.di Klinik/BP Anisa Tahun 2021

\begin{tabular}{|c|c|c|c|c|c|c|c|c|}
\hline \multirow{3}{*}{ No } & \multirow{3}{*}{$\begin{array}{l}\text { Pendidikan } \\
\text { Ibu }\end{array}$} & \multicolumn{4}{|c|}{ Imunisasi } & \multirow{3}{*}{$\mathrm{N}$} & \multirow{3}{*}{$\%$} & \multirow[b]{2}{*}{ P Value } \\
\hline & & \multicolumn{2}{|c|}{ Lengkap } & \multicolumn{2}{|c|}{$\begin{array}{c}\text { Tidak } \\
\text { Lengkap }\end{array}$} & & & \\
\hline & & $\mathrm{n}$ & $\%$ & $\mathrm{n}$ & $\%$ & & & Pvalue \\
\hline 1. & Rendah & 4 & 15 & 30 & 85 & 34 & 100 & 0,000 \\
\hline 2. & Tinggi & 9 & 60 & 3 & 40 & 12 & 100 & Bermakna \\
\hline & Jumlah & 13 & & 33 & & 46 & & \\
\hline
\end{tabular}

Berdasarkan tabel 2 diatas dari 12 responden ibu yang pendidikan tinggi yang Status Imunisasi (DPT-HB-Hib) Pada Bayi tidak lengkap sebanyak 3 bayi $(40 \%)$ dan responden yang pendidikan tinggi yang Status Imunisasi (DPT-HB-Hib) Pada Bayi lengkap sebanyak 9 bayi (60\%) dan dari 34 responden pendidikan ibu rendah yang Status Imunisasi (DPT-HB-Hib) Pada Bayi tidak lengkap sebanyak 30 bayi (85\%) dan responden yang pendidikan rendah Status Imunisasi (DPT-HB-Hib) Pada Bayi lengkap sebanyak 4 bayi (15\%). 
Sedangkan berdasarkan uji statisti Chi Square, $\mathrm{df}=1$ dan batas kemaknaan $\alpha$ $=0,05$ dan didapat $p$ value $=0,000<0,05$. hal ini menunjukkan ada hubungan antara pendidikan ibu dengan Status Imunisasi (DPT-HB-Hib) Pada Bayi sehingga hipotesis menyatakan ada hubungan antara pendidikan ibu dengan Status Imunisasi (DPT-HB-Hib) Pada Bayi terbukti secara statistik.

\section{Hubungan Antara Keterjangkauan} Tempat Pelayanan Kesehatan dengan Status Imunisasi (DPT-HB-Hib) Pada Bayi.

Keterjangkauan Tempat Pelayanan Kesehatan dibagi menjadi 2 katagori yaitu terjangkau dan tidak terjangkau. Sedangkan pada Status Imunisasi (DPTHB-Hib) Pada Bayi dibagi menjadi 2 kategori yaitu lengkap dan tidak lengkap dengan responden sebanyaj 46 orang. Hasil uji Chi-Square dapat dilihat pada tabel 3 dibawah ini:

Tabel 3 Distribusi Responden Berdasarkan Keterjangkauan Tempat Pelayanan Kesehatan dengan Status Imunisasi (DPT-HB-Hib) Pada Bayi di Klinik/BP Anisa Tahun 2021

\begin{tabular}{|c|c|c|c|c|c|c|c|c|}
\hline \multirow{3}{*}{ No } & \multirow{3}{*}{$\begin{array}{c}\text { Keterjangkauan } \\
\text { Tempat Pelayanan } \\
\text { Kesehatan }\end{array}$} & \multicolumn{4}{|c|}{$\begin{array}{c}\text { Status Imunisasi } \\
\text { (DPT-HB-Hib) } \\
\text { Pada Bayi }\end{array}$} & \multirow{2}{*}{\multicolumn{2}{|c|}{ Total }} & \multirow{3}{*}{$\mathrm{P}$ Value } \\
\hline & & \multicolumn{2}{|c|}{ Lengkap } & \multicolumn{2}{|c|}{$\begin{array}{c}\text { Tidak } \\
\text { Lengkap }\end{array}$} & & & \\
\hline & & $\mathrm{n}$ & $\%$ & $\mathrm{n}$ & $\%$ & $\mathrm{~N}$ & $\%$ & \\
\hline 1. & Terjangkau & 9 & 75 & 3 & 25 & 12 & 100 & $P$ value \\
\hline 2. & Tidak Terjangkau & 4 & 15 & 30 & 85 & 34 & 100 & 0,000 \\
\hline & Jumlah & 13 & & 34 & & 46 & & Bemakna \\
\hline
\end{tabular}

Berdasarkan tabel 3 di atas dari 12 responden yang mengatakan masih terjangkau dengan tempat pelayanan kesehatan sebanyak 3 bayi (25\%) yang
Status Imunisasi (DPT-HB-Hib) Pada Bayinya tidak lengkap dan 9 bayi (75\%) dari 12 responden yang Status Imunisasi (DPTHB-Hib) Pada Bayinya lengkap, dan dari 34 responden mengatakan tidak terjangkau dengan tempat pelayanan kesehatan sebanyak 30 bayi (85\%) yang Status Imunisasi (DPT-HB-Hib) Pada Bayinya tidak lengkap dan sebanyak 4 bayi (15\%) yang Status Imunisasi (DPT-HB-Hib) Pada Bayinya lengkap

Berdasarkan uji statistik Chi Square df $=1$ dengan batas kemaknaan $\alpha=0,05$ dan didapatkan $p$ value $=0.000<0,05$ hal ini menunjukkan ada hubungan antara Keterjangkauan Tempat Pelayanan Kesehatan dengan Status Imunisasi (DPTHB-Hib) Pada Bayi sehingga hipotesis menyatakan ada hubungan antara Keterjangkauan Tempat Pelayanan Kesehatan dan Status Imunisasi (DPT-HBHib) Pada Bayi terbukti secara statistik.

\section{PEMBAHASAN}

Penelitian ini dilakukan di Klinik/BP Anisa Tahun 2021 dengan menggunakan pendekatan Cross Sectional. Penelitian ini hanya terbatas mencari hubungan antara variabel independen (Pekerjaan, Pendidikan dan Keterjangkauan Tempat Pelayanan Kesehatan) dan variabel dependen (Status Imunisasi (DPT-HB-Hib) Pada Bayi). Adapun sampel dalam penelitian ini adalah semua ibu yang datang membawa bayinya, usia $\geq 1$ tahun untuk melakukan imunisasi ke Klinik/BP Anisa pada bulan Juni sampai dengan November Tahun 2021 sebanyak 46 responden.

\section{Hubungan Pekerjaan Ibu dengan Status Imunisasi (DPT-HB-Hib)}

Pada Bayi Pada penelitian ini, pekerjaan responden dikelompokkan menjadi 2 kategori, yaitu bekerja dan tidak bekerja. Dari hasil penelitian persentase responden yang bekerja dan Status 
Imunisasi (DPT-HB-Hib) Pada bayinya lengkap sebanyak 12 responden $(41,4 \%)$ dan dari responden yang bekerja dan Status Imunisasi (DPT-HB-Hib) Pada Bayinya tidak lengkap sebanyak 17 responden $(58,6 \%)$.

Hasil uji statisti Chi Square pada variabel pekerjaan ibu dengan Status Imunisasi (DPT-HB-Hib) Pada Bayi diperoleh $\mathrm{df}=1$ dengan $p$ value $=0,016<\alpha$ $=0,05$. Maka dapat disimpulkan bahwa ada hubungan yang bermakna antara pekerjaan ibu dengan Status Imunisasi (DPT-HB-Hib) Pada Bayi di Klinik/BP Anisa Tahun 2021 karena ibu yang bekerja waktu untuk membawa anaknya ke pelayanan kesehatan untuk mendapatkan imunisasi pentavalen tidak ada waktu sehingga Status Imunisasi (DPT-HB-Hib) Pada Bayinya tidak lengkap.

Hal ini sesuai dengan penelitian Nanda Salsabila Itsa at dkk, 2018, yang menyatakan bahwa pekerjaan ibu merupakan salah satu faktor yang mempengaruhi Status Imunisasi (DPT-HBHib) pada bayi dari sampel sebanyak 42 orang keseluruhan ibu yang memberikan imunisasi pentavalen kepada anaknya adalah ibu dengan status tidak bekerja (100\%). Sedangkan Ibu yang tidak memberikan imunisasi lanjutan Pentavalen pada balitanya sebanyak $66,7 \%$ yang bekerja dan 33,3\% tidak bekerja. Hasil uji statistik diperoleh $\mathrm{p}$ value sebesar 0,014 maka dapat disimpulkan bahwa terdapat hubungan bermakna antara status pekerjaan ibu dengan status imunisasi (DPT-HB-Hib) pada bayi dan balita.

Sehingga hipotesis yang menyatakan ada hubungan pekerjaan ibu dengan status imunisasi (DPT-HB-Hib) pada bayi di Klinik/BP Anisa Tahun 2021 terbukti statistik.

\section{Hubungan Pendidikan Ibu dengan Status Imunisasi (DPT-HB-Hib) pada Bayi}

Pada penelitian ini, pendidkan ibu dikelompokkan menjadi 2 kategori, yaitu tinggi dan rendah. Dari hasil penelitian persentase responden yang berpendidikan rendah dan status imunisasi (DPT-HB-Hib) pada bayinya lengkap sebanyak 4 responden $(15 \%)$ dan yang tidak lengkap sebanyak 30 responden (85\%).

Hasil uji statisti Chi Square pada variabel Pendidikan ibu dengan Status Imunisasi (DPT-HB-Hib) Pada Bayi diperoleh $\mathrm{df}=1$ dengan $p$ value $=0,000<\alpha$ $=0,05$. Maka dapat disimpulkan bahwa ada hubungan yang bermakna antara pendidikan ibu dengan Status Imunisasi (DPT-HB-Hib) Pada Bayi di Klinik/BP Anisa Tahun 2021 Menurut asumsi peneliti ada hubungan pendidikan ibu dengan Status Imunisasi (DPT-HB-Hib) Pada Bayi karena semakin tinggi pendidikan ibu tentang pentingnya imunisasi maka semakin tinggi kesadaran ibu untuk melengkapi imunisasi dasar pada bayinya.

Hal ini sesuai dengan teori Notoatmodjo yang menyatakan bahwa pendidikan ibu merupakan faktor dominan yang sangat penting dalam pembentukan tindakan seseorang. Berdasarkan pengalaman dan penelitian, disimpulkan perilaku yang didasari oleh pendidikan akan lebih langgeng daripada perilaku yang tidak didasari oleh pendidikan.

Seseorang mempunyai pendidikan yang tinggi mengenai suatu hal, akan menimbulkan kesadaran yang menyebabkannya berperilaku sesuai dengan pendidikan yang dimilikinya itu. Begitupun tentang Status Imunisasi (DPTHB-Hib) Pada Bayi juga tergantung pada pendidikan ibu semakin baik kesadaran ibu untuk mengimunisasikan bayinya (Notoatmodjo, 2007). 
Sehingga hipotesis yang menyatakan ada hubungan pendidikan ibu dengan status imunisasi (DPT-HB-Hib) pada bayi di Klinik/BP Anisa Tahun 2021 terbukti statistik.

\section{Hubungan dengan Keterjangkauan} Tempat Pelayanan Kesehatan dengan Status Imunisasi (DPT-HB-Hib) Pada Bayi

Pada penelitian ini, keterjangkauan tempat pelayanan kesehatan responden dikelompokkan menjadi 2 kategori, yaitu terjangkau dan tidak terjangkau. Dari hasil penelitian ibu yang jarak tempat tinggalnya dengan pelayanan kesehatan masih terjangkau dan Status Imunisasi (DPT-HBHib) Pada Bayinya lengkap sebanyak 9 responden $(75 \%)$ dan yang tidak lengkap sebanyak ibu yang jarak tempat tinggalnya jauh dengan pelayanan kesehatan (tidak terjangkau) dan Status Imunisasi (DPTHB-Hib) bayinya lengkap sebanyak 30 responden (85\%).

Hasil uji statisti Chi Square pada variabel Keterjangkauan Tempat Pelayanan Kesehatan dengan Status Imunisasi (DPT-HB-Hib) pada bayi diperoleh $\mathrm{df}=1$ dengan $p$ value $=0,000<$ $\alpha=0,05$. Maka dapat disimpulkan bahwa ada hubungan yang bermakna antara Keterjangkauan Tempat Pelayanan Kesehatan dengan Status Imunisasi (DPTHB-Hib) pada bayi di Klinik/BP Anisa Tahun 2021 Sedangkan dari hasil penelitian peneliti ada hubungan Keterjangkauan Tempat Pelayanan Kesehatan dengan Status Imunisasi (DPTHB-Hib) pada bayi karena tempat tinggal yang jauh dari fasilitas kesehatan maka semakin susah ibu untuk pergi ke fasilitas kesehatan tersebut apalagi jika jalan atau akses jalan yang rusak, licin jika hujan, berdebu bila musim kemarau.
Hal ini tidak sesuai dengan penelitian Nanda Salsabila Itsa dkk yang mengatakan salah satu faktor lain yang juga mempengaruhi pencapaian derajat kesehatan termasuk pemberian kelengkapan imunisasi adalah adanya keterjangkauan untuk mencapai tempat pelayanan kesehatan dalam hal ini puskesmas posyandu. Faktor yang mempengaruhi keterjangkauan ini ditentukan oleh adanya transportasi yang tersedia sehingga dapat memperkecil jarak tempuh dan berujung pada peningkatan kepatuhan ibu dalam berkunjung untuk mengimunisasikan anaknya. Berdasarkan hasil penelitian yang telah dilakukan, hampir seluruh responden baik di kelompok status imunisasi pentavalen lengkap maupun tidak lengkap menyatakan bahwa tempat pelayanan kesehatan terjangkau. Hasil uji bivariat menunjukkan tidak terdapat hubungan yang signifikan antara keterjangkauan tempat pelayanan kesehatan dengan kelengkapan imunisasi. Hasil ini dapat disebabkan karena sebagian besar ibu yang berkunjung ke posyandu bertempat tinggal di sekitar posyandu tersebut. Sehingga sangat sedikit ditemukan ibu yang menyatakan bahwa tempat pelayanan kesehatan tidak dapat terjangkau. Namun demikian, terdapat penelitian serupa pada populasi ibu yang memiliki bayi usia 12-36 bulan mengenai faktor yang berhubungan dengan pemberian imunisasi dasar bayi di Kota Bandar Lampung yang juga menunjukkan bahwa tidak adanya hubungan yang bermakna antara keterjangakauan tempat pelayanan kesehatan dengan kelengkapan imunsiasi. (Nanda Salsabila Itsa at all, 2018).

Sehingga hipotesis yang menyatakan ada hubungan keterjangkauan untuk mencapai tempat pelayanan kesehatan 
dengan status imunisasi (DPT-HB-Hib) pada bayi di Klinik/BP Anisa Tahun 2021 terbukti statistik.

\section{KESIMPULAN}

Berdasarkan penelitian yang telah dilakukan dan pembahasan yang telah dikemukakan, maka dapat ditarik kesimpulan sebagai berikut : Ada hubungan pekerjaan ibu secara parsial dengan Status Imunisasi (DPTHB-Hib) pada bayi di Klinik/BP Anisa Tahun 2021, Ada hubungan Pendidikan ibu secara parsial dengan Status Imunisasi (DPT-HBHib) pada bayi di Klinik/BP Anisa Tahun 2021, Ada hubungan Keterjangkauan Tempat Pelayanan Kesehatan responden secara parsial dengan Status Imunisasi (DPT-HB-Hib) pada bayi di Klinik/BP Anisa Tahun 2021, Ada hubungan antara pekerjaan, pendidikan dan Keterjangkauan Tempat Pelayanan Kesehatan Ibu secara simultan dengan Status Imunisasi (DPT-HB-Hib) pada bayi di Klinik/BP Anisa Tahun 2021.

\section{SARAN}

\section{Kepada Pimpinan Klinik/BP Anisa}

Sebagai bahan masukan bagi Klinik/BP Anisa, khususnya bagi bidan dalam menjalankan perannya untuk mengembangkan program edukasi dan konseling kepada Ibu yang mempunyai bayi dalam pemberian imunisasi.

\section{Bagi Institusi}

Hasil penelitian dapat digunakan sebagai bahan masukan dan referensi (kepustakaan) untuk mengembangkan keilmuan dan keterampilan khususnya

\section{Kepada Peneliti dan Peneliti yang akan} datang

Untuk menambah pengetahuan dan wawasan sehingga menjadi landasan dalam memberikan pelayanan kesehatan pada masyarakat, khususnya tentang imunisasi bila peneliti bertugas nanti.
DAFTAR PUSTAKA

Andi Masyita Putri M.dkk.2021 Perbandingan Pelaksanaan Imunisasi Dasar Pada Masa Pandemi dan Non Pandemi Covid-19, UMI Medical Journal Vol.6 Issue:1 (Juni, 2021) p-ISSN: 25484079/e-ISSN: 2685-7561

Abidnego.2008. Strategi dan Pengembangan Program Imunisasi di Indonesia menjelang abad 21. Balai penerbet FK UI, Jakarta Indonesia.

Balitbangkes.2018. Hasil Utama Riset Kesehatan Dasar. Kemenkes RI.

Dirjen YanMed RI. 2015. Pedoman penyelenggaraan Imunisasi. Depkes RI.

Fanny Pradila Rahma, Antono Suryoputro, Eka Yunila Fatmasari.2019. Analisis Pelaksanaan Program Imunisasi DptHb- Hib Pentavalen Booster Pada Baduta Di Puskesmas Kota Semarang (Studi Kasus Pada Puskesmas Halmahera) Jurnal Kesehatan Masyarakat (e-Journal) Volume 7, Nomor 1, Januari 2019 (ISSN: 23563346).http://ejournal3.undip.ac.id/index. $\mathrm{php} / \mathrm{jkm}$

Ibrahim D.2016. Faktor-faktor yang berhubungan dengan pencapaian cakupan imunisasi pentavalen di wilayah kerja Puskesmas Danowudu Kecamatan Ranowulu Kota Bitung. Ejournal Sariputra. 2016;3 (1): 32-9.

Muhammad Thabran Talib, Satriani Albar.2021. Analisis Faktor Pemberian Imunisasi Dasar Lengkap Pada Bayi di Puskesmas Tamalate Makassar, Healthcare Nursing Journal - vol. 3 no. 1 (2021) hal 52-58.

Nanda Salsabila Itsa.dkk 2020.Faktor-Faktor yang Berhubungan dengan Status Imunisasi Lanjutan Pentavalen (DPT- 
HB-Hib) di Wilayah Kerja Puskesmas

Labuhan Ratu Kota Bandar Lampung

Tahun 2018, Majority Volume 9 Nomor 1 Juli $2020 \mid 135$.

Notoatmodjo, Soekidjo. 2010. Ilmu Kesehatan Masyarakat Ilmu dan Seni. Jakarta : Rineka cipta. Metodologi Penelitian Kesehatan. Jakarta : Rineka cipta

Dinas Kehatan Provinsi Sumatera Selatan.2020. Rekapitulasi cakupan imunisasi Provinsi Sumatera Selatan tahun. Dinkes Sumsel

Dinas Kesehatan Kota Palembang.2020. Rekapitulasi cakupan imunisasi kota Palembang tahun 2020. Palembang: Dinkes Kota Palembang.
Profil Klinik /BP Anisa.2020.Rekapitulasi cakupan imunisasi Klinik/BP Anisa tahun 2020. Klinik/BP Anisa: Sembawa, Kab.Banyuasin.

Vina et al.2017. Imunisasi dan pengembangan senjata Biologi. Majalah Islami. Makas

World Health Organization (WHO).2021. Global vaccine plan 2011-2020 Who LibraryCataloguing-in-Publication Data.

Kementerian Kesehatan RI.2020. Buletin Surveilans PD3I dan Imunisasi.; Available from: https://www.who.int/docs/default. .2014.Buku Ajar Imunisasi.Pusat Pendidikan dan Pelatihan Tenaga Kesehatan. 